\title{
Pengaruh Citra Merk,Kualitas Produk, Harga, dan Promosi Terhadap Kepuasan Konsumen Pengguna Motor Honda Beat
}

\author{
Agus Hariyanto \\ agushari.850@gmail.com \\ Sekolah Tinggi Ilmu Ekonomi Surakarta \\ Ari Susanti \\ santisties@gmail.com \\ Sekolah Tinggi Ilmu Ekonomi Surakarta
}

\begin{abstract}
Abstrak
The study was conducted to determine the effect of brand image, product quality, price and promotion on consumer satisfaction. The variables used in this study include brand image $\left(X_{1}\right)$, product quality $\left(X_{2}\right)$, price $\left(X_{3}\right)$, promotion $\left(X_{4}\right)$ and consumer satisfaction $(Y)$. This research was conducted with a quantitative approach with a sampling method using purposive sampling using roscoe count so that 100 respondents who use Honda Beat can be taken. Data collection techniques with a Likert scale to make it easier for respondents to fill out the questionnaire. The data analysis used is multiple linear regression analysis using SPSS tools to see the results of the data obtained. The results showed that brand image, product quality, price and promotion had a positive and significant influence on consumer satisfaction.
\end{abstract}

Keywords : brand image, customer satisfaction, price, product quality, promotion

\section{Pendahuluan}

Kehidupan sehari-hari manusia tidak lepas dari bepergian. Salah satu alat transportasi yang dapat digunakan adalah sepeda motor, karena sepeda motor dinilai lebih efisien dibanding dengan kendaraan lain dan juga harganya yang terjangkau. Sepeda motor mengalami kemajuan dari waktu ke waktu baik dari segi desain maupun kualitas produk untuk memberikan rasa puas dengan merk tertentu. Terdapat beberapa merek motor yang sampai saat ini masih dikenali masyarakat diantaranya Yamaha, Honda, Suzuki, Kawasaki, dan TVS. Yamaha dan Honda merupakan merek motor yang paling digandrungi oleh masyakat saat ini dengan persentase penjualan nasional mencapai $80 \%$ pertahun dengan kriteria motor sport, matic dan bebek. Penjualan motor matic semakin meningkat dari tahun ke tahun, dibuktikan dengan persentasi sebanyak 54,16\% di tahun 2012 dan Honda merupakan market leader penjualan motor di Indonesia.

Salah satu produk AHM adalah Honda Beat yang memiliki kapasitas mesin $110 \mathrm{cc}$ dengan desain dan fitur yang memberikan kenyamanan dan keamanan bagi penggunanya. Dalam rangka mempertahankan eksistensinya, maka diperlukan citra merek yang bagus sebagai identifikasi produk untuk memenuhi ekspektasi. Kotler dan Keller (2017) menyebutkan merek menadakan tingkat kualitas sehingga konsumen dapat melakukan pembelian ulang dengan mudah. Informasi yang tercantum dalam produk sangat mempengaruhi penilaian produk. Informasi dalam produk berupa faktor intrinsic seperti cirri gaya, karakter dan desain produk serta faktor ekstrinsik seperti merk, harga, promosi dan lain-lain.

Kualitas produk merupakan elemen yang penting untuk memberikan kepuasan kepada konsumen. Kualitas produk memberikan dampak yang besar terhadap kepuasan pelanggan,retensi, dan informasi dari mulut ke mulut. Selain kualitas produk dan citra merek, promosi juga dapat dilakukan untuk mengukur kepuasan konsumen. Promosi adalah kegiatan memasarkan produk dan mempromosikan sehingga orang tertarik untuk membeli. Harga produk adalah elemen yang penting pula, karena akan mempengaruhi tingkat penjualan. 
Penetapan harga juga harus sesuai dengan kualitas produk yang dipromosikan. Produk yang sesuai dengan ekspektasi konsumen tentu membuatnya merasa senang dan puas.

Kepuasan konsumen adalah target yang harus dipenuhi dengan memahami faktor-faktor pendorong kepuasan. Maka dari itu saya tertarik untuk melakukan penelitian untuk mengetahui pengaruh citra merek,kualitas produk,harga,dan promosi terhadap kepuasan konsumen pengguna motor Honda Beat.

\section{Landasan Teori}

\subsection{Citra Merek}

Merek adalah simbol suatu produk (Sangadji \& Sopiah, 2013). Alma (2011)menyatakan bahwa merek adalah tanda yang dapat memberi identitas suatu barang atau jasa. Dewi (2018) menyatakan bahwa merek adalah interpretasi suatu barang yang dilakukan oleh konsumen berdasarkan pengalaman yang dimiliki, sehingga disimpulkan bahwa merek adalah sebuah harapan yang dapat memberikan kepuasan serta terpenuhinya ekspektasi terhadap suatu produk sehingga menimbulkan loyalitas terhadap barang tersebut. Indikator citra merek menurut Alexander (2014) yaitu sebagai berikut:

a. Atribut produk, sesuatu yang memiliki kaitan dengan merek seperti desain, kemasan dan lain-lain

b. Kepribadian merek, yaitu cerminan dari merek itu sendiri di mata konsumen apakah memiliki citra yang baik atau memiliki citra yang buruk

\subsection{Kalitas Produk}

Tjiptono (2014) menyatakan kualitas produk adalah mutu yang diharapkan pada sebuah produk untuk memenuhi kebutuhan pengguna. Kualitas produk merupakan kinerja produk yang berperan untuk memenuhi keinginan pelanggan sehingga produk yang mempunyai kualitasnya baik dapat memberikan kepuaasan konsumen (Kotler dan Keller, 2017).

Berdasarkan beberapa definisi diatas dapat dipahami bahwa kualitas produk merupakan suatu kondisi dimana totalitas,daya tahan maupun kehandalan suatu produk atau jasa yang ditawarkan dapat memuaskan ekspektasi konsumen. Produk yang memiliki kualitas dalam Tjiptono (2015) memenuhi beberapa indikator seperti:
a. Kinerja (peforma)
b. Kesesuaian dengan spesifikasi
c. Estetika
d. Daya tahan
e. Kemudahan perbaikan.

\subsection{Promosi}

Swastha \& Handoko (2012) menyebutkan bahwa promosi merupakan kegiatan komunikasi untuk mempengaruhi seseorang supaya tertarik untuk membeli produk yang ditawarkan. Menurut Alma (2011), promosi adalah pemberian penjelasan untuk meyakinkan seseorang, mendapatkan perhatian dan mendidik agar mau membeli produk atau jasa yang ditawarkan.

Dari paparan di atas, promosi adalah alat untuk menyampaikan informasi oleh prusahaan ataupun orang lain untuk memberi penjelasan terkait produk, harga, maupun spesifikasi yang diberikan kepada konsumen. Adapun Indikator promosi menurut Kotler \& Keller (2009) adalah:
a. Pelayanan
b. Kehumasan
c. Pemasaran langsung
d. Periklanan
e. Promosi penjualan 


\subsection{Harga}

Menurut Kotler \& Keller (2009) harga merupakan sejumlah uang yang dikeluarkan untukm mendapatkan atau menggunakan jasa dan produk yang ditawarkan. Harga merupakan alat untuk memperoleh pendapatan. Simamora (2004) menyatakan bahwa harga adalah nilai berupa uang untuk memperoleh suatu produk. Penetapan harga yang tepat merupakan hal yang sangat penting dalam dunia jual beli, sehingga keuntungan bagi perusahaan dan keterjangkauan bagi konsumen perlu dipertimbangkan. Penetapan harga sangat perlu diperhitunkan karena dapat dijadikan kesempatan bagi pesaing untuk meningkatkan kualitas produknya bahkan lebih murah dengan kualitas yang sama.

Berdasarkan beberapa definisi, harga adalah nilai yang harus dikeluarkan untuk dapat memiliki atau menggunakan produk/jasa. Adapun indikator harga menurut Kotler \& Keller, (2009) adalah:
a. Kesesuaian Harga
b. Persaingan Harga
c. Periode pembayaran
d. Kredit

\subsection{Kepuasan Konsumen}

Menurut Kotler dan Keller (2017), kepuasan konsumen merupakan kondisi akhir konsumen setelah menggunakan produk atau jasa yang dapat berupa kepuasan atau kekecewaan. Perasaan senang atau kecewa seseorang yang muncul setelah membandingkan hasil. Menurut Tjiptono (2007), kepuasan konsumen adalah perbandingan hasil dari nilai yang dikeluarkan dengan ekspektasi sehingga memunculkan kondisi tertentu. Untuk itu, kepuasan konsumen merupakan hal yang sangat penting untuk diwujudkan karena dapat mempengaruhi konsumen dalam mengggunakan barang sehingga dapat meningkatkan pendapatan perusahaan melalui eksistensi produk yang ditawarkan. Adapun indikator kepuasan konsumen menurut Kotler \& Keller (2009) adalah :

a. Kualitas produk

b. Harga

c. Kualitas pelayanan

d. Promosi

\section{Metode Penelitian}

\subsection{Jenis Penelitian}

Penelitian dilakukan dengan menganalisa data yang didapatkan dari hasil survey kepada populasi yang ditentukan. Populasi dari penelitian ini adalah konsumen pengguna motor Honda Beat yang mempunyai ciri tertentu dan sesuai dengan kebutuhan penelitian yang kemudian ditarik kesimpulanya. Adapun karakteristik yang pertama yaitu usia minimal 18 tahun, dan yang kedua yaitu responden yang memiliki motor Honda Beat.

Metode pengumpulan data dilakukan dengan menyebar kuisioner yang berisi daftar pernyataan tentang kepuasan konsumen untuk diisi sehingga peneliti mendapatkan data penelitian yang diinginkan dengan relevan. Jumlah responden dalam penelitian minimal 100 orang dan diharapkan setiap responden dapat mengisi data dengan jujur sesuai dengan pengalaman yang mereka dapatkan selama menggunakan produk. Teknik analisis data menggunakan jenis non probability sampling yaitu purposive sampling. Variabel dalam penelitian ini adalah citra merek, kualitas produk ,promosi dan harga sebagai variable independent serta kepuasan konsumen sebagai variable dependent.

\subsection{Teknik Analisis Data}

Metode pada analisis yang dilakukan adalah regresi linier berganda dengan menggunakan aplikasi Package for Social Sacience (SPSS). Teknik analisis data yang digunakan oleh peneiti yakni uji instrumen, uji asumsi klasik dan uji hipotesis 


\section{Analisis dan Pembahasan}

4.1. Analisis Data

4.1.1. Uji Instrumen

a. Uji Validitas

Uji validitas dilakukan untuk mengukur valid atau tidaknya setiap butir pernyataan variabel dalam kuisioner. Apabila kuisioner dapat mengungkapkan sesuatu, maka kuisioner tersebut dapat dikatakan valid (Ghozali, 2013). Uji validitas yang diketahui jumlah sampel sebanyak 100 responden dan a = 5\%. Jika $r$ hitung lebih besar dari 0,195, maka semua butir pernyataan dapat dikatakan valid.

b. Uji Reliabilitas

Uji reliabilitas bertujuan untuk menguji kereliabilitasan kuisioner. Kuisioner yang mempunyai nilai koefisien alpha 0,6 dinyatakan butir pernyataan kuisioner dapat dikatakan reliable (Ghozali, 2013). Hasil uji reliabilitas menggunakan cronbach alpha adalah setiap variabel antara lain 0,612 (citra merek), 0,817 (kualitas produk), 0,651 (harga), 0,647 (promosi) dan 0,765 (kepuasan pembelian). Jadi instrument dalam penelitian ini dapat dikatakan reliable.

\subsubsection{Uji Asumsi Klasik}

a. Uji Normalitas

Menurut Ghozali (2013), model regresi normal apabila data ploting dalam data sesungguhnya mengikuti garis diagonal. Uji ini dilakukan untuk melihat normal atau tidaknya nilai residu. Uji normalitas dari penelitian ini diperoleh nilai signifikan sebesar $0,897>0,05$ artinya nilai residual berdistribusi normal.

b. Uji Multikolinearitas

Berdasarkan hasil output SPSS maka ditemukan hasil tolerance $\mathrm{X}_{1}$ dengan nilai 0,631 > 0,1 , nilai VIF variabel $X_{1} 1,584<10$. Variabel $X_{2}$ dengan nilai tolerans $0,529>0,1$, nilai VIF $1,891<10$. Variabel $X_{3}$ dengan nilai tolerans $0,753>0,1$, nilai VIF sebesar $1,329<10$. Dan variabel $\mathrm{X}_{4}$ dengan nilai tolerans $0,697>0,1$, nilai VIF sebesar $1,435<10$. Artinya keempat variabel independen tidak terjadi multikolinearitas.

c. Uji Heteroskedastisitas

Berdasarkan hasil output SPSS maka ditemukan nilai signifikan citra merek 0,253 kualitas produk, 0,708 harga, 0,957 promosi 0,131. data yang didapatkan menunjukan bahwa variabel citra merek, kualitas produk, harga, dan promosi tidak ada gejala heteroskedastisitas karena nilai residual >0,05.

\subsubsection{Uji Regresi Linier Berganda}

Tabel 1.Hasil uji Regresi Linier Berganda

\section{Coefficientsa}

\begin{tabular}{|c|c|c|c|c|c|c|}
\hline \multirow[t]{2}{*}{ Model } & & \multicolumn{2}{|c|}{$\begin{array}{l}\text { Unstandardized } \\
\text { Coefficients }\end{array}$} & $\begin{array}{l}\text { Standardized } \\
\text { Coefficients }\end{array}$ & \multicolumn{2}{|c|}{ Sig. } \\
\hline & & B & $\begin{array}{l}\text { Std. } \\
\text { Error }\end{array}$ & Beta & & \\
\hline 1 & (Constant) & -.011 & 1.119 & & -.010 & .992 \\
\hline & Citra_Merk & .445 & .138 & .270 & 3.234 & .002 \\
\hline & Kualitas_Produk & .193 & .063 & .279 & 3.054 & .003 \\
\hline & Harga & .316 & .109 & .223 & 2.912 & .004 \\
\hline & Promosi & .238 & .087 & .218 & 2.738 & .007 \\
\hline
\end{tabular}

a. Dependent Variable: Kepuasan_Konsumen

Berdasarkan hasil SPSS diperoleh persamaan garis regresi yaitu:

$$
Y=-0,11+0,445\left(X_{1}\right)+0,193\left(X_{2}\right)+0,316\left(X_{3}\right)+0,238\left(X_{4}\right)+e
$$


Penjabaran dari persamaan regresi diatas antara lain:

1) Nilai konstanta sebesar -0,11. Sehingga kepuasan konsumen pada nilai variabel independent yaitu variabel citra merek, kualitas produk, harga dan promosi menurun sebesar $-0,11$.

2) Nilai koefisien citra merek sebesar 0,445 artinya setiap kenaikan satu skor untuk citra merek akan diikuti dengan meningkatnya kepuasan konsumen sebanyak 0,445.

3) Nilai koefisien kualitas produk senilai 0,193 artinya apabila skor kualitas produk meningkat, maka kepuasan konsumen juga akan meningkat sebanyak 0,193.

4) Nilai koefisien harga sebesar 0,316 artinya setiap kenaikan satu skor untuk harga akan diikuti dengan kepuasan konsumen sebanyak 0,316.

5) Nilai koefisien promosi sebesar 0,238 artinya setiap kenaikan satu skor untuk promosi akan diikuti dengan kepuasan konsumen sebanyak 0,238.

4.1.4. Uji t

Berdasarkan hasil uji di atas, maka diperoleh hasil:

1) Variabel $X_{1}$ menunjukan t hitung dengan nilai 3,234 dengan nilai signifikan 0,002 $<0,05$ sehingga hipotesis diterima dan mmiliki dampak positif terhadap kepuasan konsumen.

2) Variabel $X_{2}$, t hitung sebesar 3,054, nilai signifikan 0,003 $<0,05$ yang artinya hipotesis diterima dan berpengaruh positif terhadap kepuasan konsumen.

3) Variabel $X_{3}$ memperlihatkan thitung sebesar 2,912 dengan nilai signifikan 0,004<0,05 artinya hipotesis diterima dan memiliki pengaruh positif terhadap kepuasan konsumen.

4) Variabel $X_{4}$, t hitung sebesar 2,738, nilai signifikan 0,007 $<0,05$ sehingga hipotesis diterima dan berpengaruh positif terhadap kepuasan konsumen.

\subsubsection{Uji F}

Tabel 2. Hasil Uji F

ANOVA $^{\mathrm{a}}$

\begin{tabular}{llrrrrr}
\hline Model & & Sum of & & Mean & & \\
\hline 1 & Rquares & df & Square & \multicolumn{1}{c}{ F } & Sig. \\
& Regression & 150.956 & 4 & 37.739 & 33.048 &, $000^{\mathrm{b}}$ \\
& Residual & 108.484 & 95 & 1.142 & & \\
& Total & 259.44 & 99 & & & \\
\hline
\end{tabular}

a. Dependent Variable: Kepuasan_Konsumen

b. Predictors: (Constant), Promosi, Harga, Citra_Merk, Kualitas_Produk

Berdasarkn hasil uji output SPSS maka dapat dikatakan nilai $\mathrm{F}$ hitung sebesar 33,048 dengan nilai signifikan $0,000<0,05$ yang artinya citra merek, kualitas produk, harga, promosi berpengaruh secara stimultan atau bersama sama terhadap kepuasan konsumen.

\subsubsection{Koefisien Determinasi}

Tabel 3. Koefisien Determinasi Model Summary

\begin{tabular}{|c|c|c|c|c|}
\hline \multirow[b]{2}{*}{ Model } & \multicolumn{4}{|c|}{ Adjusted } \\
\hline & $\mathrm{R}$ & $\begin{array}{c}\mathrm{R} \\
\text { Square }\end{array}$ & $\begin{array}{c}\mathrm{R} \\
\text { Square }\end{array}$ & $\begin{array}{l}\text { Std. Error of } \\
\text { the Estimate }\end{array}$ \\
\hline 1 & ,763a & .582 & .564 & 1.06861 \\
\hline
\end{tabular}

a. Predictors: (Constant), Promosi, Harga, Citra_Merk, Kualitas_Produk 
Berdasarkan hasil uji output SPSS dapat ditemukan bahwa nilai Adjusted R Square sebesar 0,564 yang artinya citra merek, kualitas produk, harga, promosi mampu menjelaskan tentang faktor-faktor kepuasan konsumen. Sedangkan 0,436 dipengaruhi oleh variabel lain.

\subsection{Pembahasan}

\subsubsection{Pengaruh Citra Merk Terhadap Kepuasan Konsumen}

Berdasarkan hasil uji regresi, maka citra merek memiliki pengaruh positif dan signifikan terhadap kepuasan konsumen pengguna motor Honda Beat. Hal ini membuktikan penelitian terdahulu yang telah dilakukan oleh Jannah (2019) dimana hasil penelitian variabel citra merek berpengaruh positif pada kepuasan konsumen

\subsubsection{Pengaruh Kualitas Produk Terhadap Kepuasan Konsumen}

Berdasarkan hasil uji regresi, maka kualitas produk memiliki pengaruh yang baik dan signifikan kepuasan konsumen pengguna motor Honda Beat. Artinya yaitu Honda Beat telah memberikan kualitas produk yang baik dan dapat memuaskan konsumen. Hal ini membuat penelitian yang dilakukan oleh Jannah (2019) menunjukan variabel kualitas produk memiliki pengaruh yang positif terhadap kepuasan konsumen

\subsubsection{Pengaruh Harga Terhadap Kepuasan Konsumen}

Berdasarkan hasil uji regresi, maka pengaruh dari variabel harga $\left(\mathrm{X}_{3}\right)$ terhadap kepuasan konsumen berpengaruh positif dan signifikan terhadap kepuasan konsumen pengguna motor Honda Beat. Artinya yaitu harga telah sesuai dengan kualitas yang diberikan pada konsumen sehingga konsumen merasa puas terhadap produk Honda Beat. Hal ini membuktikan bahwa penelitian yang dilakukan oleh Jannah (2019) menunjukan variabel harga memiliki pengaruh yang positif dan signifikan terhadap kepuasan konsumen.

\subsubsection{Pengaruh Promosi Terhadap Kepuasan Konsumen}

Berdasarkan hasil uji regresi, maka promosi memiliki dampak yang nyata dan positif terhadap kepuasan konsumen pengguna motor Honda Beat. Artinya yaitu promosi dapat meyakinkan konsumen dengan terhadap kepuasan konsumen. Hal ini menunjukan terdapat pengaruh yang signifikan pada variabel promosi terhadap kepuasan konsumen pada penelitian yang dilakukan oleh (Nurhanifah, 2014)

\section{Kesimpulan dan Rekomendasi}

\subsection{Kesimpulan}

Berdasarkan penelitian ini, maka dapat disimpulkan sebagai berikut :

a. Variabel citra merek $\left(\mathrm{X}_{1}\right)$ berpengaruh secara signifikan atau positif terhadap kepuasan konsumen. Sehingga hipotesis pertama diterima.

b. Variabel kualitas produk $\left(\mathrm{X}_{2}\right)$ berpengaruh secara signifikan atau positif terhadap kepuasan konsumen. Sehingga hipotesis kedua diterima.

c. Variabel harga $\left(\mathrm{X}_{3}\right)$ berpengaruh secara signifikan atau positif terhadap kepuasan konsumen sehingga hipotesis ketiga diterima.

d. Variabel promosi $\left(\mathrm{X}_{4}\right)$ berpengaruh secara signifikan atau positif terhadap kepuasan konsumen sehingga hipotesis keempat diterima.

e. Kepuasan konsumen (Y) dipengaruhi secara bersama-sama atau secara simultan dari variabel citra merek, kualitas produk, harga, dan promosi.

\section{2. $\quad$ Rekomendasi}

Berdasarkan penelitian diatas, maka peneliti ingin memberikan saran sebagai berikut:

a. Untuk manajemen Honda agar dapat mempertahankan variabel independen (Citra Merek, Kualitas Produk, Harga, Promosi) karena hal tersebut memiliki pengaruh yang positif terhadap kepuasan konsumen. 
b. Untuk selanjutnya peneliti berharap agar digunakan untuk bahan perbandingan referensi penelitian serta memperdalam penelitian selanjutnya dengan mengembangkan variabel independen diluar penelitian ini.

\section{Daftar Pustaka}

Alma, B. (2011). Manajemen Pemasaran dan Pemasaran Jasa. Bandung: Alfabeta.

B. Alexander, D. (2014). Analisa Pengaruh Citra Merek (Brand Image) dan Kepercayaan Merek (Brand Trust) Terhadap Loyalitas Merek (Brand Loyalty) ADES PT. Ades Alfindo Putra Setia. Jurnal Manajemen Pemasaran Petra, 2(1), 1-9.

Dewi, S. N. (2018). Kekuatan Preferensi Pengalaman Sebagai Solusi Peningkatan Niat Melanjutkan Pembelian Produk. Yogyakarta: Penerbit Deepublish.

Ghozali, I. (2013). Aplikasi Analisis Multivariete. In Badan Penerbit Universitas Dipenegoro.

Jannah, A. M. (2019). Pengaruh Promosi, Kualitas Produk Dan Kualitas Pelayanan Terhadap Keputusan Menabung Nasabah Bank Syariah. Journal of Chemical Information and Modeling, 53(9), 1689-1699. Retrieved from file:///C:/Users/win7/Downloads/PENGARUH PROMOSI, KUALITAS PRODUK DAN KUALITAS.pdf

Kotler dan Keller. (2017). Manajemen Pemasaran, Edisi 12, Jilid 1, PT.Indeks,. Jakarta. In $e-$ Jurnal Riset Manajemen.

Kotler, P., \& Keller, K. L. (2009). Manajemen pemasaran Jilid 1. In Jakarta.

Nurhanifah, A. (2014). Analisis Pengaruh Kualitas Pelayanan, Promosi Dan Lokasi Terhadap Kepuasan Konsumen (Studi Kasus Pada PT. Maharani Tri Utama Mandiri Cabang Semarang). Fakultas Ekonomika Dan Bisnis Universitas Diponegoro Semarang, 1-76.

Sangadji, E. M., \& Sopiah. (2013). Perilaku Konsumen : Pendekatan Praktis Disertai Himpunan Jurnal Penelitian. Yogyakarta: Penerbit Andi.

Simamora, H. (2004). Manajemen sumber daya manusia (3rd ed.). STIE YPKN.

Swastha, B., \& Handoko, T. H. (2012). Manajemen Pemasaran: Analisa Perilaku Konsumen. Yogyakarta: BPFE UGM.

Tjiptono. (2007). Strategi Pemasaran, edisi kedua.

Tjiptono, F. (2014). Pemasaran Jasa - Prinsip, Penerapan, dan Penelitiab. Bandung: Penerbit Andi. Tjiptono, \& Fandy. (2015). Strategi Pemasaran (Edisi 4). Yogyakarta: Penertbit Andi. 
